\title{
Evropské oceňovací standardy a jejich význam pro oceňování podniku
}

\author{
Miloš Mařik ${ }^{1}$
}

Oceňování majetku se stává stále důležitější praktickou a v souvislosti s tím i teoretickou disciplinou. Vedle tradičních podnětů k oceňování, jako jsou zdanění majetku při různých př́ležitostech a různé majetkové spory, se oceňování stává stále častějším prvkem hospodářské činnosti. Jako př́klad lze uvést oceňování zástav v rámci poskytování úvěrů, oceňování nepeněžitých vkladů všeho druhu, oceňování podniků a akcií v rámci podnikových transformací atd.

Problém je v tom, že s rozvojem oceňovacích aktivit nedrží vždy krok péče o jejich kvalitu. Oceňování provádějí zpravidla soudní znalci, kteří byli jmenováni soudy, případně ministrem spravedlnosti. Na rozdíl od jiných oblastí znalecké činnosti není dosud v České republice (a nebyl ani dříve) vypracován jednotný systém jak zajistit kvalitu zpracovávaných ocenění. Tento systém by zahrnoval jednak odbornou př́pravu znalců a odhadců, tj. odborníků zaměřených na oceňování majetku, a jednak obecně přijímané postupy oceňování, které by měly být při vypracování oceňovacích posudků dodržovány.

Současná praxe v České republice je taková, že znalci a odhadci majetku jsou organizováni asi v šesti znaleckých organizacích, z nichž některé se do jisté míry snaží připravovat určitá doporučení jak při ocenění postupovat. Jedinou obecnou normou platnou na území České republiky je však zákon č. 151/1997 Sb. o oceňování majetku a navazující vyhlášky. Tento zákon ovšem platí jen pro některé případy, jako např. pro oceňování majetku investičních fondů apod.

Běžné oceňování pro komerční účely zatím není v České republice na rozdíl od většiny vyspělých zemí nijak regulováno. Nejde samozřejmě o regulaci státní, spíše o regulaci prováděnou znaleckými organizacemi, která pak nabývá podobu národních oceňovacích standardů. Většina západoevropských zemí dnes disponuje oceňovacími standardy, tj. doporučeními pro znalce, jak při ocenění postupovat, především pro oblast oceňování nemovitostí. Za nejvýznamnější lze zřejmě považovat standardy britské a německé (např.Wertermittlungsverordnung 1988). Poněkud méně propracována je oblast oceňování podniků. Našim podmínkám je asi nejbližší německý IDW Standard č. 1 (IDW Standard: Grundsätze zur Durchführung von Unternehmensbewertungen).

Standardizace na národní úrovni však při dnešních podmínkách globalizujícího se hospodářství již nepostačuje, a proto dochází ke snahám standardizovat oceňovací postupy na mezinárodní úrovni. V České republice je dobře známé, že se dlouhodobě pracuje na sjednocování postupů finančního účetnictví, přičemž formou tohoto sjednocování jsou Mezinárodní účetní standardy. Méně známou skutečností je, že již od 70. let se pracuje i na Mezinárodních oceňovacích standardech. V 70. letech proto vznikla světová organizace znalců a odhadců (International Valuation Standards Committee), která vydává postupně upravované Mezinárodní oceňovací standardy (IVS - International Valuation Standards).

1 Prof. Ing. Miloš Mařík, Katedra financí a oceňování podniku Fakulty financí a účetnictví Vysoké školy ekonomické v Praze. 
Mezinárodní oceňovací standardy lze považovat, při jejich dnešní úrovni, za určitý obecný základ pro oceňovací činnost na celém světě. Nelze si však představovat, že se jedná o jakýsi návod k použití. Tyto standardy jsou psány na velmi obecné úrovni a jejich jádrem je vymezení hlavních typů (standardů) hodnoty. Tzn., že definují možné výsledky ocenění, které označují jako standardy hodnoty. Přitom se předpokládá, že různým podmínkám a účelům ocenění odpovídají i různé standardy hodnoty. Za nejdůležitější je třeba považovat definici tržní hodnoty spolu s rozvedením podmínek, za kterých je výsledek znaleckého úsilí možno označit jako tržní hodnotu. Tato skutečnost je důležitá zejména pro naše podmínky, protože v České republice se většina znalců domnívá, že každé ocenění, které není sestaveno podle zmíněného oceňovacího zákona a jeho prováděcích vyhlášek, lze automaticky označit za ocenění tržní. Mimo definici tržní hodnoty pak Mezinárodní oceňovací standardy vymezují celou řadu standardů hodnoty, které označují jako netržní.

K Mezinárodním oceňovacím standardů je však třeba poznamenat, že vycházejí především ze zájmů a potřeb národních znaleckých organizací, které se zabývají z větší části oceňováním nemovitostí. Proto také v těchto standardech dominuje pohled na nemovitosti, případně jednotlivý movitý majetek, zatímco oceňování podniků je zde zmíněno pouze doplňkově.

Vznik světové organizace odhadců byl doprovázen vznikem obdobné organizace na úrovni Evropy, která se nazývá TEGoVA (The European Group of Valuers' Associations). Tato organizace sdružuje národní znalecké asociace a vypracovává Evropské oceňovací standardy (EVS - European Valuation Standards). Evropské oceňovací standardy nabývají na významu pro české znalce a odhadce zejména v souvislosti se vstupem České republiky do Evropské unie.

V návaznosti na úvodní poznámky vymezíme i účel tohoto článku:

1. stručně popsat obsah Evropských oceňovacích standardů a jejich vazbu na standardy světové,

2. podrobněji vymezit tržní hodnotu jako základní standard hodnoty,

3. v rámci evropských oceňovacích standardů podrobněji analyzovat směrnici pro oceňování podniků, a to především z pohledu běžné praxe v České republice,

4. vymezit možnosti použití Evropských oceňovacích standardů jako východiska pro přípravu českého standardu pro oceňování podniku.

\section{Evropské oceňovací standardy - obecná charakteristika}

Evropské oceňovací standardy do jisté míry navazovaly na přijetí 4. direktivy Evropské unie, jejímž smyslem byla harmonizace ročních finančních výkazů a výročních zpráv o společnostech. Smyslem bylo (mimo jiné) harmonizovat zásady pro oceňování dlouhodobých aktiv ve finančních výkazech. V souvislosti s tím vznikla i evropská definice tržní hodnoty, ze které Evropské oceňovací standardy také vycházejí.

Evropské oceňovací standardy se skládají z vlastních standardů, směrnic a dodatků. Standardů je celkem 9 , z nichž za nejdůležitější lze považovat zejména:

- Standard č. 2, který vymezuje nároky na kvalifikaci znalce, 
- Standard č. 4, který je svým způsobem nejdůležitějuš́, protože obsahuje různé definice tržních a netržních základů ocenění, a okolnosti, za kterých je vhodné je aplikovat. Patři sem:

a) tržní hodnota (Market Value),

b) tržní nájemní hodnota (Market Rental Value)

c) EU tržní hodnota (EU Market Value),

d) férová hodnota (Fair Value),

e) hodnota při stávajícím využití (Existing Use Value),

f) hodnota při alternativním využití (Alternative Use Value),

g) amortizované náklady náhrady (Depreciated Replacement Cost).

- Standard č. 5 - oceňování pro finanční výkazy (Valuation for the purpose of Financial Reporting),

- Standard č. 6-oceňování pro účely zajišstění pủjček a hypoték (Valuations for the purpose of securing loans and mortgage-backed securities on properties/real estate),

- Standard č. 8 - oceňování pro investiční společnosti a pojištovny (Valuations for Investment - Insurance Companies, Property Unit Trust, and Pension Funds, etc).

Na 9 standardů navazuje 10 směrnic (guidance notes), které jsou zaměřeny na řešení speciální otázek. Např.:

- Směrnice č. 3 se soustřed'ujena oceňování vybavení závodů (Valuation of Plant a Machinary),

- Směrnice č. 5 - oceňování zemědělského majetku (Valuation of Agricultural Properties),

- Směrnice č. 7 - oceňování podniků (Business Valuations),

- Směrnice č. 8 - oceňování nehmotných aktiv (Valuations of Intangible Assets).

Poslední část se týká dodatků, jejichž nejdůležitější součástí je slovník základních pojmů.

Jádrem evropských oceňovacích standardů EVS i světových oceňovacích standardů IVS je definice (standard) tržní hodnoty. V této souvislosti je třeba poznamenat, že IVS jsou poněkud obecnější a tvoří základ pro EVS. EVS vycházejí z IVS a v některých částech se liší.

Pro definici tržní hodnoty je tedy proto vhodné opírat se především o IVS. Zde je definována především obecně hodnota a její vztah $\mathbf{k}$ ceně, jak ji dlouhodobě chápe znalecká praxe. Definice uvádíme především proto, že v laické i odborné veřejnosti vládnou značné nejasnosti:

„Cena je pojem, který souvisí se směnou výrobku, zbožínebo služby. Cena je částka, která byla požadována, nabizena nebo zaplacena za danou položku. Kdyžje transakce uskutečněna, cena, at’ už zveřejněná nebo nezveřejněná, se stává historickou skutečností. Zaplacená cena predstavuje průsečík nabidky a poptávky.

Pojem hodnota označuje nejpravděpodobnější cenu, na které by se dohodli kupujicí a prodávajicí daného zboží nebo služby nabizené k prodeji. Hodnota představuje hypotetickou nebo teoretickou cenu, na které by se kupujicí a prodávajicí s největši pravděpodobností dohodli za dané zboži nebo službu. Hodnota tedy neni skutečnost, ale odhad nejpravděpodobnějši ceny, která bude zaplacena za zboží nebo službu nabízenou ke koupi v daném čase". (IVS úvod ke standardu 1 a 2, body 3.1. a 3.3)." 
Kromě schopnosti být koupen a prodán účastníky trhu, tj. kupujícími a prodávajícími, může být hodnota zboží nebo služby odvozena z alternativního ekonomického užitku nebo funkcí spojených s ní nebo může odrážet neobvyklé nebo netypické tržní podmínky, jak uvádějí následující odstavec 3.4 této části standardů:

3.4.1 Vlastníci majetku držící podnik, investoři do tohoto majetku, pojistitelé majetku, daňoví poradci nebo ratingoví pracovníci, likvidátoři a př́íjemci a atypicky motivovaní nebo zvláštní kupující mohou přiřazovat různé hodnoty stejnému majetku ze stejně racionálních a platných důvodů.

3.4.2 Byly vytvořeny speciální definice hodnoty, které dávají možnost alternativních hodnot, které mohou být přiřazeny zboží nebo službě. Použití termínu hodnota by proto mělo být vždy vymezeno konkrétní použitelnou definicí.“”

Mezinárodní standardy důsledně rozlišují dvě skupiny pohledů na hodnotu. Především je to hodnota tržní (market value) a pak netržní varianty hodnoty.

\section{Tržní hodnota jako základní standard hodnoty}

Základem jak EVS tak IVS je, jak již bylo řečeno, především definice tržní hodnoty. Nejpodrobněji je popsána v IVS, obdobné pojetí je pak přebíráno i do EVS. V IVS je tržní hodnota chápána takto:

„Tržní hodnota (market value) je představitelem hodnoty při směně, je to částka, kterou by majetek přinesl, pokud by byl nabídnut k prodeji na (otevřeném) trhu ke dni ocenění za podmínek, které vyhovují požadavkům definice tržní hodnoty. Za účelem stanovení tržní hodnoty musí odhadce nejprve odhadnout nejvyšší a nejlepší využití (highest and best use), nebo nejpravděpodobnější použití (viz. IVS Obecné pojmy a principy oceňování, odst. $6.3,6.4,6.5)$. Toto využití může být při pokračování stávajícího využití majetku nebo při nějakém alternativním využití. Tato rozhodnutí se provádějí na základě údajů z trhu.

Tržní hodnota je navržena prostřednictvím aplikace oceňovacích metod a postupů, které odrážejí podstatu majetku a podmínky, za kterých by mohl být daný majetek nejpravděpodobněji obchodován na (otevřeném) trhu. Nejběžnějšími metodami pro stanovení tržní hodnoty jsou nákladová metoda (cost approach), metoda porovnání prodeju (sales comparison approach) a metoda kapitalizace výnosủ (income kapitalisation approach) včetně analýzy diskontovaného cash flow.“

Povšimněme si jedné důležité věci. Tržní hodnota zde není chápána pouze jako hodnota převzatá př́mo z trhu, jak se to někdy chápe v České republice (toto chápání se často objevuje v normách vydávaných MFČR). Tržní hodnota může být navržena i např́íklad pomocí výnosového ocenění, pokud vstupní data pro toto ocenění jsou stanovena základě tržních dat. Tržní hodnotu je možno stanovit pomocí všech tř́i základních oceňovacích př́stupů.

Další důležitou věcí je předpoklad nejlepšího možného využití se kterým definice tržní hodnoty pracuje.

2 Srov. IVS, Úvod ke standardu 1 a 2, část 3.1-3.4. 
Vlastní definice tržní hodnoty (IVS + TEGoVA) má pak tuto podobu:

„Tržní hodnota je odhadnutá částka, za kterou by majetek měl být směněn k datu ocenění mezi dobrovolným kupujicím a dobrovolným prodávajícím v nezávislé transakci po náležitém marketingu, při které každá strana jedná informovaně, rozumě a bez nátlaku."

Vzhledem k významu tržní hodnoty uvedeme i vysvětlující poznámky uvedené ve Standardu (srov. IVS, Standard č. 1, část 3.2):

„Každý prvek definice má svůj vlastní pojmový rámec“

„Odhadnutá částka ... “ představuje cenu vyjádřenou v penězích (obvykle v místní měně), která by byla zaplacena za aktivum v nezávislé tržní transakci. Tržní hodnota je měřena jako nejpravděpodobnější cena rozumně dostupná na trhu k datu ocenění v souladu s definicí tržní hodnoty. Je to nejlepší rozumně dostupná cena pro prodávajících a nejvýhodnější rozumně dostupná cena pro kupujícího. Tento odhad především vylučuje odhad ceny zvýšené nebo snížené zvláštními faktory nebo okolnostmi, jako je atypické financování, prodej a dohoda o zpětném pronájmu, zvláštní hlediska nebo výhody poskytované někým, kdo je s prodejem spojen, nebo jakýkoli prvek zvláštní hodnoty (special value) (definované v IVSC Standardu 2, odst. 3.11).

„... majetek měl být směněn... “ odráží skutečnost, že hodnota majetku je odhadnutá částka, nikoli předem určená částka nebo skutečná prodejní cena. Je to cena, za kterou trh očekává, že by byla provedena transakce ke dni ocenění pro splnění všech ostatních částî definice tržní hodnoty.

„... k datu ocenění... “vyžaduje, aby odhad tržní hodnoty byl časově omezen. Protože se trhy a tržní podmínky mohou změnit, odhadnutá hodnota může být v jiné době nesprávná nebo nevhodná. Ocenění bude odrážet aktuální tržní stav a podmínky existující ke skutečnému datu ocenění a ne $\mathrm{k}$ minulému nebo budoucímu datu. Definice také předpokládá současnou směnu a provedení prodeje bez jakýchkoli cenových variant, které by někdy mohly být prováděny.

„...mezi dobrovolným kupujícím.. “" odkazuje na toho, kdo je motivován, ale ne nucen ke koupi. Tento kupující není ani př́liš dychtivý ani nucen kupovat za každou cenu. Tento kupující je také ten, kdo kupuje podle situace na současném trhu a podle aktuálních tržních očekávání, a ne podle imaginárního nebo hypotetického trhu, u kterého nelze prokázat nebo předpokládat, že existuje. Případný kupující by neměl zaplatit vyšší cenu, než jakou požaduje trh. Současný vlastník majetku je zahrnut mezi ty, kteří tvoř́í „trh“. Odhadce nesmí udělat nerealistické předpoklady ohledně tržních podmínek ani předpokládat úroveň tržní hodnoty vy̌šśí, než jaká je rozumně dostupná.

„....dobrovolný prodávající..." není ani př́iliš dychtivý ani není nucen k prodeji za jakoukoli cenu, ani není připraven nabízet za cenu, která nepřichází na současném trhu rozumně v úvahu. Dobrovolný prodávající je motivován k prodeji majetku na trhu za nejlepší cenu dosažitelnou na (otevřeném) trhu po náležitém marketingu, ał už je tato cena jakákoli. Skutečná situace stávajícího vlastníka daného aktiva není součástí těchto úvah, protože „dobrovolný prodávající“ je hypotetický vlastník.

„...vv nezávislé transakci... “ je transakce mezi stranami, které nemají mezi sebou blízké nebo zvláštní vztahy (např. mateřská a dceřiná společnost nebo vlastník a nájemce), které by mohly způsobit, že by cena nebyla pro trh typická nebo by byla zvýšená v důsledku prvku zvláštní hodnoty (definované v IVSC Standardu 2, odst. 3.11). Transakce za tržní hodnotu se předpokládá mezi nesouvisejícími stranami, z nichž si každá počíná nezávisle. 
„...po náležitém marketingu.. “znamená, že by majetek měl být na trhu vystaven nejvhodnějším způsobem tak, aby za něj byla získána nejlepší cena rozumně přicházející v úvahu při splnění definice tržní hodnoty. Délka doby vystavení se může měnit v závislosti na podmínkách trhu, ale musí být dostatečná k tomu, aby majetek mohl být zaznamenán odpovídajícím počtem potenciálních kupujících. Období vystavení předchází datu ocenění.

„... prri které každá strana jedná informovaně a racionálně... “ předpokládá, že jak dobrovolný kupující tak dobrovolný prodávající jsou rozumně informováni o podstatě a charakteristikách majetku, jeho skutečném a potenciálním využití a stavu trhu k datu ocenění. Dále se předpokládá, že každý jedná s touto znalostí a rozumně ve vlastním zájmu a usiluje o nejlepší cenu pro svoji pozici v transakci. Rozumnost je dána vztahem ke stavu trhu k datu ocenění a ne výhodami vzniklými tak, že bychom situaci posuzovali někdy později již se znalostí minulého vývoje. Není nezbytně nerozumné, když prodávající prodá majetek na trhu s klesajícími cenami za cenu, která je nižší než předchozí tržní cena. V takovýchto případech, tak jak je tomu v ostatních situacích prodejů a koupí na trzích s měnícími se cenami, bude rozumný kupující nebo prodávající reagovat podle nejlepších tržních informací $\mathrm{k}$ danému datu.

„... a bez nátlaku ... “ stanovuje, že každá strana je motivována k podniknutí transakce, ale ani jedna není nadměrně nucena ji uskutečnit.“

Je třeba zdůraznit jednu okolnost - tržní hodnota je chápána jako hodnota aktiva bez zahrnutí nákladů prodeje nebo koupě a bez kompenzace za související daně.

V běžné praxi je tržní hodnota používána jako oceňovací základna pro nespecializovaný majetek oceňovaný ve vztahu k finančním výkazům a je odlišována od ostatních základen, které by neměly být použity.

Pro úplnost ještě uved'meže podle Evropské Direktivy 91/647/EEC, článku 49 (2) je tržní hodnota definována obdobně:

„Tržní hodnota znamená cenu, za kterou by mohly být pozemky a budovy prodány $v$ soukromém kontraktu mezi dobrovolným prodávajicím a samostatným a nezávislým kupujícím k datu ocenění, přičemž je předpokládáno, že majetek je veřejně na trhu, tržní podmínky dovolují organizovaný prodej a je dostupná normální doba k jednání o prodeji, vzhledem k povaze majetku“(91/647/EEC in EVS 2000, str. 33).

Tato definice se pouze vztahuje k účelům specifických Direktiv EU ${ }^{13}$. Organizace evropských znalců a odhadců TEGoVA je přitom toho názoru, že použití obou definic umožňuje dosáhnout stejného výsledku.

Z dalších definic hodnoty uváděných v EVS zmíníme pouze ty, které považujeme za významné pro ocenění podniku.

První z nich je Férová hodnota (fair value, EVS, Standard 4, odst. 4.36 a 4.37). EVS k férové hodnotě uvádějí:

„Férová hodnota je účetní pojem zahrnutý v Mezinárodních účetních standardech (IAS 16.6). Tato hodnota je definována jako „hodnota, za kterou může být aktivum směněno mezi ochotnými stranami, které mají dostatek informací a nejsou v žádném jiném

3 Definice EU, má specificky podrobné požadavky zabývající se vykazováním pro účely účetnictví a požaduje doplňující komentář k účtủm, je speciálně vyžadována pro ocenění pro pojistný sektor, a/nebo může být vynucena klientem nebo jeho profesionálním poradcem, či požadována z titulu, jako reprezentujíć jedinou právní definici tržní hodnoty dle práva EU (EVS 2000, str. 29). 
vztahu“. Dále se odstavec 29 a následující IAS 40 zabývají použitím férové hodnoty u investičních nemovitostí.

Je třeba podotknout, že přiměřená hodnota, zmiňována v jiných částech IAS, může být totožná s tržní hodnoto, ale zcela se tyto dva pojmy nekryjí. Důležité je, že fair value je používána v některých zemích jako právní definice hodnoty při určování nestranného vyrovnání mezi stranami soudního sporu, nebo sporu, u kterého se uvažuje o soudním rrízení.“

Druhou často i u nás používanou bází hodnoty jsou amortizované reprodukční náklady (Depreciated Replacement Cost). Tento způsob ocenění patří k netržním oceňovacím bázím. EVS uvádějí následující vymezení (Standard 4, S 4.84), které je samo o sobě dostatečně výstižné:

„Amortizované reprodukční náklady (DRC) jsou oceňovací metodou pro stanovení hodnoty při stávajícím využití či užitné hodnoty specializovaných nemovitostí, které jsou na trhu zřídka, jestli vůbec, prodány nebo pronajímány jiným způsobem než jako součást celého podniku. Nejsou považovány za metodu odvozenou od trhu, s výjimkou ocenění pozemku jako součásti nemovitosti. Avšak některé analýzy, které se použivají při tržním ocenění, jsou založeny na údajích, které jsou odvozeny od DRC analýzy prodeje nemovitostí. Chybí-li jakákoli tržní data, DRC často slouží jako náhrada za tržní analýzu. DRC jsou proto nevhodné u nemovitostí, které jsou drženy pro investiční účely, nebo jsou pro provoz dané společnosti nadbytečné.“

Pro oceňování podniku považujeme v souladu s převládající teorií i praxí za rozhodující především standard tržní hodnoty. Pokud je ocenění podniku postaveno na majetkovém ocenění, nebo toto ocenění obsahuje jako součást souhrnného ocenění, setkáváme se často i s oceněním na principu DRC (i když se tento pojem u nás prakticky nepoužívá a hovoří se spíše o nákladovém ocenění. Oba pojmy však nelze považovat za synonyma).

Fair value se uplatňuje především jako nový prvek účetních výkazů a je proto definována hlavně v Mezinárodních účetních standardech a na tyto standardy navazující poslední verzi našich účetních předpisů. Domnívám se však, že i nás by bylo možno uvažovat o fair value jako o hodnotovém standardu použitelném např́ílad v oceňovacích posudcích pro soudní spory.

Dále se budeme zabývat Směrnicí EVS pro oceňování podniků. Je třeba říci, že tato Směrnice již dnes ve většině ustanovení v zásadě odpovídá postupům uplatňovaným v české oceňovací praxi i teorii. Proto se soustředíme na ty části, které jsou zatím s naší oceňovací praxí více méně v rozporu.

\section{EVA Směrnice 7 (Guidance 7) - Oceňovaní podniku}

Tato směrnice je vedle Standardů hodnoty pro oceňování podniku nejdůležitější. Má poměrně obecná charakter a nezabývá se podrobně vlastními metodami oceňování. Vychází, mimo jiné, ze zásady, že znalci je třeba ponechat dostatečnou volnost a vymezit pouze určitý rámec pro jeho činnost.

Z hlediska naší praxe považujeme za důležité, že:

- Směrnice klade značný důraz na dostatečnou kvalifikaci oceňovatelů. Mimo obecných kvalifikačních požadavků typu školního vzdělání je třeba zvláště zdůraznit požadavek na „znalosti sektoru a předmětu podnikání:“ Ocenění vyžaduje blízký styk s klientem a jeho profesionálními poradci a určitých případech př́istup ke ko- 
merčnímu poradenskému servisu pro zajištění toho, že oceňovatel má detailní znalosti a rozumí jak sektoru, tak předmětu podnikání. Zdůraznění tohoto bodu se zdá být nadbytečné, poněvadž uvedený požadavek je možno považovat za samozřejmost. Bohužel znalci v České republice si myslí opak.

- Směrnice rozlišuje jako cíl ocenění jednak hodnotu podniku (tj. hodnotu podniku jako celku, hodnotu brutto) a hodnotu kapitálovou (tedy ocenění na úrovni vlastního kapitálu).

Např́íklad kapitálová hodnota je definována takto: „Hodnota podniku je odhadovaná částka, bez jakýchkoliv srážek za znehodnocení a amortizaci, která však zohledňuje všechen majetek a závazky, za kterou by byl k datu ocenění směněn emitovaný akciový kapitál mezi nespřízněným poptávajícím kupujícím a nabízejícím prodávajícím po odpovídající tržní transakci, při níž každá ze stran měla dostatek informací, jednala racionálně a bez nátlaku“. (GN 7.04). Toto rozlišení je v souladu s českou praxí.

- Z německých standardů byl zřejmě převzat názor, že oceňovatel může vystupovat v jedné z následujících profesionálních funkcí (GN 7.06):

- Jako nezávislá osoba, která předkládá ocenění zohledňující plány a současná očekávání dotyčného podniku jako základ pro vyjednávání. Jako nezávislá osoba musí oceňovatel podnik ocenit z pohledu průměrného investora. Výsledkem je tržní ocenění, které nepřihlíží k subjektivním vlivům specializovaného kupujícího.

- Jako odborný poradce při transakci, který, na základě zhodnocení pravděpodobných výsledků, pro svého klienta představí scénář nejlepší varianty (maximální prodejní cena nebo minimální kupní cena). Pokud působí jako odborný poradce, mohou smluvní podmínky zakázky oceňovatele zahrnovat poskytování rad klientovi při jednáních o ceně. Oceňovatelovo ocenění je potom subjektivní v tom, že obecně bere $\mathrm{v}$ úvahu jak odhady svého klienta, tak i své vlastní modely budoucí výkonnosti. $V$ tomto případě by odborný poradce také zdůraznil kritické otázky pro použití v nezávislém vyjednávání o nejpříznivějším výsledku (minimální prodejní cena nebo maximální kupní cena). „Subjektivní " hodnota podniku se obvykle liší od nezávislého ocenění. Potenciální kupující může například očekávat synergický efekt ze sloučení předmětného koncernu se svým vlastním podnikem a/nebo kvůli dalším prvkům svého podnikatelského plánu nebo budoucí souvislost s podnikáním, pokud by podnik zůstal samostatný nebo v rukou konkurenta.

- Jako rozhodce, který určí své rozhodnutí o ceně s přihlédnutím k návrhům jak prodávajícího, tak i kupujícího. Rozhodnutí o ceně mohou ovlivnit zákonná ustanovení, existující smlouva nebo mínění zúčastněných stran.

- Významné je, že Směrnice uvádí u nás již poměrně obvyklé rozdělení majetku na provozní a neprovozní (GN 7.10)

- Zásadní otázkou, ke které se Směrnice vyjadřuje, je, zda je možno určit tržní ocenění pro podnik. Nejvýraznější odpovědnalezneme v GN 7.16, kde se uvádí: „Tak jako u ostatních druhů majetku musí být oceňovací metodika, pokud je to možné, v souladu se závaznými požadavky direktiv EU a vyjadřovat obecně přijímaný př́istup kupujících na trhu. Pokud je ocenění odvozeno z tržních faktů a očekávaných výnosů jiných subjektů průmyslového odvětví, je výsledkem tržní hodnota podniku. Pokud je ocenění založeno na subjektivních kritériích a požadavcích investo- 
ra, bude výsledkem „subjektivní“ hodnota podniku“. Podle našeho názoru totéž platí, když znalec víceméně vychází z názorů a dat předkládaných klientem.

- Podle Směrnice je oceňovatel povinen věnovat pozornost i věcem, které u nás oceňovatele zpravidla nezajímají. Musí například přihlédnout i k „vývoji dodavatelů spojených s odvětvím, klientů, současných konkurentů, substitučních výrobků a budoucích konkurentů (včetně překážek pro vstup na trh nebo opuštění trhu); k budoucí konkurenční pozici podniku ve srovnání se rovnocennými subjekty v odvětví; k relativní síle, strategii a potenciálu hlavních konkurentů.

Oceňovatel přitom podle Směrnice musí identifikovat:

- trh pro dotyčnou podnikatelskou jednotku a druh majetku, musí ji zevrubně chápat a znát síly, které ji ovládají. Bude také potřebovat mít povědomí o jakýchkoli změnách v kulturních stylech, podnikatelských trendech, dostupnosti dluhového a kapitálového financování a ekonomii nabídky a poptávky v odvětví; také o rozsahu a rozložení jakékoliv současné nebo očekávané konkurence, o jakýchkoli možných změnách v dopravní infrastruktuře, geografické poloze nebo socioekonomickém profilu zákaznické základny. Ve zprávě o ocenění budou výše zmíněné faktory začleněny tak, aby byly relevantní pro stanovení hodnoty (GN 7.22),

- „hodnotový řetězec podniku(value chain)“ “ ${ }^{1}$ (GN 7.17),

- „kritické faktory“ podniku, což znamená faktory, které určují, zda je podnik úspěšný či ne.

- Oceňovatel musí zajistit, aby bylo volné cash flow v souladu s prognózovaným vývojem odvětví, odhady budoucí tržní pozice podniku a jeho hlavních konkurentů. (GN 7.28)

Dalším důležitým bodem, kterému není v naší praxi i teorii věnována dostatečná pozornost je analýza rizik. Standardy v této souvislosti vyzdvihují analýzu citlivosti. (GN 7.30):

„Účelem analýzy citlivosti je zajistit, aby ocenění adekvátně vyjadřovalo riziko. Analýza citlivosti identifikuje specifické rizikové faktory, které nejvíce přspívají $k$ celkovému riziku. Existují dvě základní tř́dy rizika společnosti, riziko podnikání a finanční riziko. Riziko podnikání je nejistotou př́jmů způsobené fluktuacív prodejích a úrovni fixních a variabilních nákladi̊. Finanční riziko odráží dopad fixních finančních nákladi̊ nebo kolísajících úrokových měr a jejich dopad na zisky investorù. V konečném di̊sledku by analýza citlivosti měla integrovat pravděpodobnost přřazenou rizikovým faktorům a odvozené proměnné, mezi jiným z vyhodnocení podnikové historie, systematických a strukturních složek“.

Budoucí nejistoty jsou spojeny s ( GN 7.31):

- přesností předpovídaných podnikových aktivit beroucích v potaz běžné konkurenční prostředí;

- vývojem domácích a zahraničních trhů;

- cenovými změnami základních surovin a ostatních vstupů včetně dopadu přímých a nepřímých daní. 
Standardy, které se normálně vyhýbají tomu, aby byly př́liš konkrétní, se analýze citlivosti věnují poměrně podrobně a ještě uvádějí (GN 7.32):

\section{kolika metod:}

- formulace scénářů založená na nejpesimističtějších, nejpravděpodobnějších a nejoptimističtějších předpokladech,

- použití sestupných pravděpodobnostních faktorů na odhadovaný př́ijem,

- diskontování odhadovaných př́ijmů vzestupnými diskontními sazbami.“.

K řadě důležitých a sporných momentů se EVS ale vyslovují jen velmi stručně. Jedná se např́íklad o tyto problémy:

- jak stanovit reziduální hodnotu při výnosovém ocenění (především metodou DCF).

- jak určovat prémii za majoritu a diskonty za nižší likvidnost a za minoritu. Tento problém je ovšem poměrně palčivý a zůstává otevřený zřejmě v celém světě.

Naproti tomu Směrnice jednoznačně podporují pravidlo, které se u nás prosazuje jen dost obtižně a to, že druhá varianta výnosového ocenění - ocenění na základě účetně pojatých výsledků hospodaření (zisků) nemůže zpravidla vycházet př́mo z údajů uváděných v účetních výkazech, ale že tyto výsledky je nutno upravovat v souladu s požadavky oceňovací teorie. EVS k tomu uvádějí (GN 7.38):

„Oceňovatel musí stanovit reprezentativní úroveň takového přijmu, který je udržitelný $v$ budoucnosti a to bude obvykle čistý roční př́iem nebo př́jem z provozní činnosti po zdanění. Podstatnou skutečností je, že se nejedná o účetní hodnoty získanéz výkazu zisků a ztrát, ale jsou to hodnoty, které byly upraveny, aby odrážely ekonomicky běžné a reprodukovatelné budoucí př́jmy. Úpravy musí eliminovat dopad přechodných, neopakovatelných nebo náhodných vlivů na př́jmy a výdaje. “

Opět se jedná o záležitost, kterou naše znalecká obec př́liš nebere v potaz a která je přitom velmi důležitá, poněvadž má podstatný vliv na výsledek ocenění a zároveň mají doporučené úpravy více nebo méně propracovaný teoretický základ (srov. např. Bellinger: Unternehmensbewertung in Theorie und Praxis, Wiesbaden, Gabler 1992). Jedná se tedy o další příklad, kdy rozsáhlejší uplatnění EVS by umožnilo výrazně zdokonalit české oceňovací posudky.

Je však také třeba uvést, že některé přístupy EVS mohou být považovány za poněkud sporné. Mám na mysli např́íklad GN 7.45, kde se doporučuje použít pro majetkové ocenění především tržních hodnot. Jedná se sice o názor, který je i ve světě značně rozšířený, má však prokazatelně své výrazné slabé stránky. Jejich precizní analýzu z účetního hlediska podala v posledním období zejména prof. Kovanicová (srov. Účetnictví č.1.,2, 3, ročník 2004).

Uvedenou skutečnost považuji především za důkaz, že již nejsme pouze v situaci, kdy bylo nutné jen přebírat to, co přichází ze zahraničí, ale že začínáme být schopni se podílet na diskuzích o dalším vývoji standardů. 


\section{Závěry}

Pokusme se nyní zformulovat několik nejdůležitějších závěrů, které plynou z tohoto pojednání ve vztahu k teorii a praxi oceňování podniku:

1. Se vstupem do Evropské unie lze předpokládat, že se zvýší význam Mezinárodních oceňovacích standardů pro praxi i teorii oceňování v České republice.

2. Vzhledem k úzké provázanosti Evropských oceňovacích standardů EVS se standardy světovými IVS se ve většině př́ípadů nebude možno omezovat pouze na EVS.

3. Základem oceňovacích standardů jsou především definice hodnoty, především pak hodnoty tržní. Tržní hodnota, tak jak ji definují IVS, je dnes ve světě nejčastěji užívaným standardem hodnoty.

4. V České republice je tržní hodnota i základním používaným standardem hodnoty pro oceňování podniků. Tento přístup odpovídá názorům obsaženým v EVS. Problém však spatřujeme $\mathrm{v}$ tom, že nejsou v české praxi dostatečně respektovány požadavky, které EVS stanovují pro hledání tržní hodnoty. Na řadu těchto př́ípadů bylo poukázáno $v$ předchozím textu. $V$ tomto bodě ale oceňovací praxe $v$ České republice nedrží tak zcela krok s teorií (srov. M. Mařík a kol.: Metody oceňování podniků, Praha, Ekopress 2003).

5. Vedle tržní hodnoty však mezinárodní (i národní standardy Německa, USA a dalších zemí) definují řadu dalších standardů hodnoty, které však nejsou zatím v praxi př́liš využívány. Bude předmětem dalšího výzkumu, které z dalších ve světě navrhovaných standardů hodnoty využívat v České republice, přičemž máme na mysli hlavně oceňování podniků.

6. Předchozí závěr pak úzce souvisí s otázkou, do jaké míry a za jakých podmínek existuje tržní hodnota obecně, do jaké míry a za jakých podmínek existuje pro podniky. Také tato otázka je předmětem dalšího výzkumu, který probíhá na VŠE.

7. Předchozí závěry by měly sloužit jako jedno z východisek pro tvorbu předpokládaných Českých oceňovacích standardů. 


\section{Literatura}

1. BRETZKE, W.: Unternehmungsbewertung in dynamischen Märkten, BfuP 1/93

2. International Accounting Standards 2000.

3. IDW Standard 2000.

4. International Valuation Standards 2001, European Valuation Standarts 2001.

5. KROG, M.: Marktorientierung und gesellschaftsrechtliche Unternehmensbewertung. Deutscher Universitäts-Verlag, Wiesbaden, 2000.

6. MANDL, G. - RABEL, K.: Unternehmensbewertung. Ueberreuter 1997. Wien.

7. MAŘÍK a kol.: Metody oceňování podniku, Ekopress 2003, Praha.

8. PeeMöller, V. H.: Praxishandbuch der Unternehmensbewertung. 2001.

9. PRATT, S. P. - REILLY, R. F. - SCHWEIHS, R. P.: Valuing a Business. New York, McGraw-Hill, 2000.

10. SCHNEIDER, D.: Marktwertorientierte Unternehmensbewertung: Pegasus mit Klumpfuss, Der Betrieb, Juli 1988.

11. The Dictionary of Real Estate Appraisal.3. vydání, Chicago, Appraisal Institute, 1993.

12. WP Handbuch, 11. vydání, díl II. IDW 1998. 